Jaroslav Korecko,

Ph.D., University of Presov, Slovakia

Radovan Bacik,

Ph.D., Associate Professor, University of Presov, Slovakia

Iveta Voznakova,

Ph.D., Associate Professor, University of Business and Law, Czech Republic

\title{
PUBLIC ADMINISTRATION IN EU: HARMONIZATION OF INCOME TAXES
}

\begin{abstract}
In the European communities, the need for tax harmonization has begun to commence since the beginning of integration efforts in the 1960s. The first attitudes to tax harmonization were very ambitious. The plan was not only structural harmonization but also harmonization of tax rates. The paper examines the nature and course of the direct tax harmonization process, describes its advantages and disadvantages as well as the positive and negative effects of tax competition. The paper aims to examine the development and volume of selected income taxes collected in the Member States of the European Union. It tells whether the harmonization of income taxes is still a stagnant process. Cluster analysis deals with looking for similarities of multidimensional objects. Two clustering methods were used - hierarchical agglomeration clustering and non-hierarchical clustering. Cluster analysis aimed to achieve groups of states that would have some homogeneity. Cluster analysis sorted the data into sets with the highest possible similarity within the group and the most significant difference between the groups. Analysis of tax burden and income tax rates confirmed significant differences in these indicators across the EU. On the other hand, cluster analysis revealed similar developments in tax systems in terms of their geographical location in Europe. Cluster analysis can be used to suggest possible steps to co-operate in harmonizing Member State taxes in the future. The authors of this article propose the possibility of harmonizing taxes and cooperating gradually within clusters rather than trying to apply uniform rules in all EU Member States at the same time. The conclusion of the article raises problems in the field of harmonization of direct taxes in the EU. The possibility of preserving autonomy in deciding on tax burden in the country is left to the many Member States because they see that autonomy as a competitive advantage, particularly in the field of investment.
\end{abstract}

Keywords: tax, harmonization, income, European Union, cluster analysis.

Introduction. The different economic, political and social development in different parts of Europe have also been reflected in specific tax characteristics, as well as in entire tax systems (Kiselakova et al., 2018; Tkacovaet al., 2017; Simionescu, 2016). Significant differences, for direct taxes, can be followed between taxes of Western or Northern Europe (Belgium, Denmark, France, Netherlands, Germany) and the taxes of Eastern European countries (Bulgaria, Romania, Slovakia and the Czech Republic). There are significant differences in the rates for income taxes. In the past, citizens of transit economies were not accustomed to a high tax burden, especially for income taxes (up to $70-80 \%$ in developed countries), and therefore such a burden in our countries would not be acceptable. Nevertheless, the rising interdependence of economies in the European Union is linked to the growing interest in international aspects of public finances (Ivanova, Cepel, 2018; Belas et al. 2018a, b; Vojtovic, 2016). The creation of a common market in Europe, the growing influence of multinational corporations, and financing of joint activities within integration clusters have highlighted the need for tax coordination, respectively harmonization. Appropriate tax harmonization of EU Member States' tax policies is a serious economic and political issue that governments must seriously address to maintain economic progress and economic stability.

At present, countries are joined in different integration clusters. They cooperate and depend on each other. Reasons are both, political and economic, such as strengthening the position on defence, creating competitive economies, expanding markets, and the like. There is a lot of effort needed to make this cooperation work effectively. To make the cooperation as easy as possible, there are efforts to

Cite as: Korecko, J., Bacik, R. \& Voznakova, I. (2019). Public Administration in EU: Harmonization of Income Taxes. Marketing and Management of Innovations, 4, 280-291. http://doi.org/10.21272/mmi.2019.4-22 
standardize, coordinate and harmonize the greatest possible number of processes, laws, directives, regulations, etc. (Kocisova et al. 2019). The European Union is a typical example of such a cluster. The processes of international coordination and harmonization in the EU also affects the taxes and tax systems of the Member States. The paper aims to explore selected aspects of most important direct taxes (Personal Income Tax - PIT, and Corporate Income Tax - CIT) in the Member States. The task is to assess the reality of the harmonizing idea in the Union and to suggest possible progress in this process soon. The theoretical part of the presented scientific article describes the development of tax harmonization, as well as the advantages and disadvantages of harmonization according to various authors. Cluster analysis performed in statistical software R 3.3.3 was used as a research method for data analysis. Two methods of clustering were used - hierarchical agglomeration clustering and non-hierarchical clustering. Cluster analysis aimed to achieve groups of states that have some homogeneity. Cluster analysis sorted the data into sets with the highest possible similarity within the group and the largest differences between the groups. A possible gradual harmonization of taxes in the EU can be proposed based on cluster analysis.

Literature Review. The European Union is currently undergoing several changes, including the Brexit process, which may affect its future form. Tax systems that have been fragmented so far are a barrier to the functioning of the EU's single internal market. It is expected that due to the current changes, the integration system, including the tax system, will be more flexible (Riedel, 2018). Although the harmonization of tax law and the role of the Court of Justice within the EU has many critics, its more than sixty-year history is used to exploit the evolution of tax law in the Eurasian Economic Union as a model of integration that has shown significant results over decades (Ponomareva, 2016). The current tax framework in the EU leaves Member States free to choose their tax system if they comply with the rules unanimously adopted by the EU Council. If Member States' tax policies violate the principles of the single market, the EU is empowered to take decisions to ensure protection against tax fraud and evasion, as well as to suppress aggressive tax planning (Niazi, 2016). This is done primarily through more effective tax cooperation and exchange of tax information between states. Much of the demands and priorities have emerged in the context of strengthening tax policy and tax justice. In the area of corporate taxation or combating harmful competition and aggressive tax planning, targets are set to reduce the number of loopholes resulting from several complex rules, assessment bases and rates that may apply to individual businesses (Douma and Kardachaki, 2016). The deepening integration of the European Communities and the demands for increased coordination in the tax area have led to an increase in the difficulty of enforcing these measures, as they were perceived primarily by the Member States as interfering with their national sovereignty. Based on this fact, tax harmonization has ceased to be the objective of the European Commission and has started to serve primarily as a tool necessary to achieve a functioning single market. In 1997, the European Council adopted the so-called tax package, which was a set of measures to combat harmful tax competition, as well as measures to promote tax coordination within the European Communities. At the same time, the tax package sought to reduce the inequalities that existed in taxation, but at the same time allowed the Member States to make changes to tax systems that helped employment. The contents of the package consisted of three main parts:

- the so-called Code of Conduct for BusinessTaxation;

- measures to achieve a higher degree of approximation of systems for savings income taxation;

- an agreement to remove withholding tax on interest payments and royalties where there is a need to act in a coordinated manner so as not to undermine the development of investments (Cnossen, 2018; Finke et al. 2014).

Tax competition is defined as the use of a tax policy that will make it possible to maintain or increase the attractiveness of particular territory for business placement. A comparative analysis of income tax rates in EU countries has confirmed that the phenomenon of tax competition is still very strong. The question arises as to whether tax competition is a real problem for the EU Member States and if so, whether there 
are arguments for tax harmonization. Tax competition and tax coordination have supporters and opponents. Empirical studies do not show that tax competition leads to significant income losses. While tax competition is a real threat to public finances, it can be questioned whether tax coordination is the appropriate solution. A single fiscal policy will likely have a positive impact on the EU economy as a whole, but specific countries would be forced to implement fiscal policies that may not be in line with their interests at a given point in time.

Therefore, a cautious approach to tax coordination would be appropriate and focus should be on relatively minor adjustments rather than on full harmonization of corporate tax rates (Dzialo, 2015). Most tax competition analyses focus on direct impacts on corporate tariffs and incomes. This focus is too narrow because it overlooks the fact that competition for legal entities also has a significant indirect impact on the progressiveness and potential of raising personal income tax revenues (Ganghof, Genschel, 2008). In particular, in recent years, the European Union has reassessed the objectives of tax policy and, in addition to promoting the smooth functioning of the single market, the aim is to ensure fairness in taxation. It is emphasized that taxation must be fair - a tax system in one country should not provide the entities with unfair advantages compared to other competitors in another state. Concerning natural persons, fair taxation is seen as a situation where the Member States do not allow people to escape taxation in another state. To date, there are relatively significant differences between the tax burden associated with income from employment in the individual EU Member States. Concerning tax proceedings, the difference is mainly in the setting of the tax base for the calculation of tax liability (Psenkova, 2016). Legislators need to prepare a legislative concept that is not only in line with all EU intentions and regulatory requirements but also acceptable to national taxpayers when preparing country tax system adjustments. Moreover, it is important to realize that tax harmonization is followed by changes in the accounting legislation of the individual European countries (Hakalova et al. 2018). The European Commission launched a debate on the gradual transition to more effective taxation decisions in the EU. The Commission Communication builds on Juncker's 2018 speech on the state of the Union, calling for a move towards QMV voting (qualified majority voting) in tax matters. At present, unanimous voting is taking place in the areas of tax policy in accordance with primary law, which imposes considerable restrictions, as new legislation is indeed difficult to adopt, and legislation once adopted is also difficult to change because any change requires unanimity again. The current situation can lead to costly delays or a complete blockage of proposals that may be relevant to growth, competitiveness and tax justice in the single market (Genschel and Jachtenfuchs, 2018).

Furthermore, the Commission envisages the introduction of majority voting for measures already harmonized across the EU, such as VAT and consumption tax, which could help individual countries and businesses in the EU to better respond to technological developments and market changes. The transition to QMV should also take place in areas such as the common consolidated corporate tax base and the new digital economy taxation system to ensure fair and competitive taxation in the EU. Experts in tax law and tax systems differ in their views on the degree of tax harmonization in the EU, as well as on the process of tax harmonization. According to Siroky et al. (2008) in the area of international tax relations, countries deal with three issues:

- how to construct import or export taxes;

- how to tax the foreign earnings of their inhabitants and earnings of foreigners originating from activities in their territory;

- how to coordinate and harmonize the tax system with tax systems in other countries.

A particular and complex problem is represented by the above-mentioned third tax line as it concerns the direct tax sovereignty of individual countries. The first step of international tax cooperation is tax coordination, resulting in various contracts, agreements, etc. Kubatova (2003) considers tax coordination as the first stage of international convergence of tax systems. It is a creation of bilateral or multilateral tax 
schemes, to limit arbitrage transactions. It addresses recommendations in key areas of harmful tax competition and recommendations for bilateral contractual relations between the Member States. She characterizes harmonization as a process of approximation and adaptation of national tax systems and individual taxes based on compliance with the common rules of participating countries. The process has three main phases:

- the choice of the tax to be harmonized;

- harmonization of the tax base;

- harmonization of the tax rate.

Some authors complement these three stages with harmonization in tax administration (Figure 1).

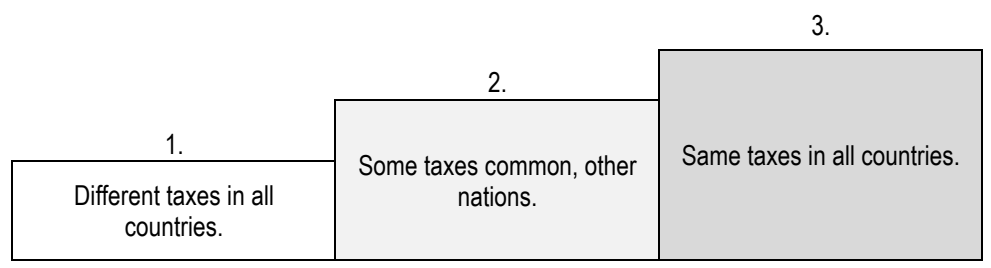

Figure 1. Levels of tax harmonization

Sources: developed by the authors.

The first extreme in the harmonization process is a full standardization of taxes in the integration group (the same tax bases, tax rates, and the same tax administration). The second extreme case in the picture is so-called zero (none) harmonization, which is the opposite of already mentioned standardization. There are, however, several other situations between these two extreme cases, which are represented by different degrees of harmonization (James, Nobes, 1999):

- double taxation treaties;

- tax administration cooperation;

- tax base harmonization;

- nominal harmonization, etc.

Nominal harmonization implies that countries have the same taxes, which do not have to be based on the same tax base or be in the same tax administration system. Tax Harmonization and Tax Competition. In recent years, there has been a constant debate in the European Union, whether it is preferable to harmonize taxes or to leave the Member States the option of independently deciding on their tax systems. Based on these discussions, it is possible to formulate positive, as well as negative aspects of both phenomena. Positives of tax harmonization (European Commission 2010, Mitchell, 2005):

- a common tax system could improve work mobility;

- eliminating «tax competition» among nations that leads to «Race to the Bottom»;

- reducing the potential for tax evasion;

- tax differences can distort the single market;

- eliminating the problem of «environmental parasitism».

Positives of tax competition (Medved, Nemec et al., 2011):

- the economic stimulus of competition;

- savings in public budgets.

Negatives of tax competition were presented by Devereux (2002) and the European Commission (2010):

- tax competition could lead to a Race to the Bottom $=>$ which could result in a long-lasting reduced supply of public goods (tax cuts below the «natural» or «viable» threshold); 
- it hurts employment, it is so-called relocating businesses to more favourable conditions (the workforce is much less mobile than capital);

- it is an obstacle to the functioning of the single market in the European Union.

Table 1 below, from Prichard et al. (2014), provides a conceptual classification of revenues other than debt. It also shows that most of government direct taxes revenue are from income taxes. Therefore, we have focused on the analysis of Personal Income Tax and Corporate Income Tax.

Table 1. Classification of different sources of government revenues

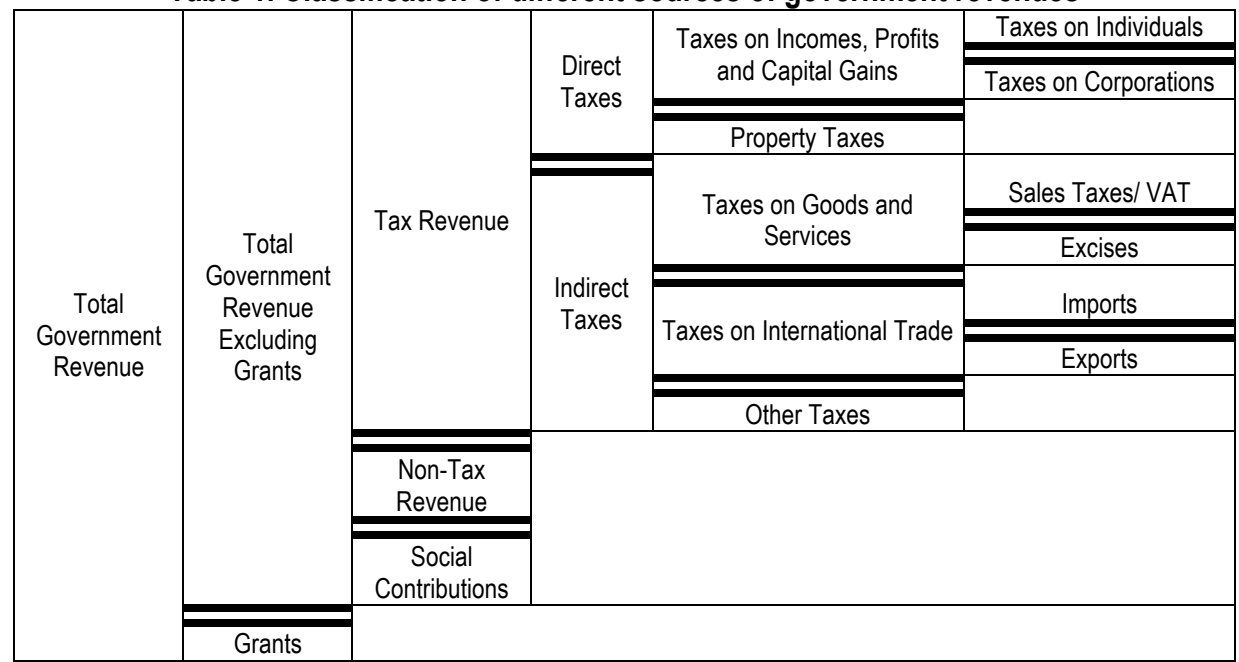

Sources: developed by the authors according to Prichard et al (2014).

In general, Personal Income Tax is a tax on a person's income from wages and salary, gambling winnings, and some other sources. Corporate Income Tax (CIT) could be defined as a tax levied on corporations' profits.

Methodology and research methods. Despite significant rises since 2010, EU-28 income tax revenue as a percentage of GDP reached a plateau in 2015, with euro area following a broadly similar trend. The structure of taxation varies quite significantly across the Member States. When it comes to the share of direct taxes in total tax revenues, Denmark has the highest share $(66 \%)$, followed by Ireland, the United Kingdom, Sweden and Malta with shares lying between $40 \%$ and $50 \%$ of revenue. Figure 2 shows the evolution of current taxes on income, wealth, etc. over the period 2006 to 2016 . The graph clearly shows that the evolution of incomes from these taxes in the EU-28 follows developments in the Euro area. Evolution suggests that the level of tax revenue has reached the level before the crisis. In particular, the Union's policy seeks to prevent tax revenues from falling outside its borders.

The average value of Personal Income Tax was 7,4\% GDP in the EU-28 in 2006. In 2016, this average indicator rose by $0,3 \%$ to $7,7 \%$ GDP. In 2016 (compared with the reference year 2006), the revenues from personal income tax rose in 19 Member Countries. The biggest increase was recorded in Denmark (2,0\%), Luxembourg $(1,9 \%)$ and Portugal $(1,7 \%)$

On the other hand, Lithuania $(-2,8 \%)$, Hungary $(-1,6 \%)$ and Sweden $(-1,4 \%)$ recorded the most marked decline in comparison to the reference year. The highest collection of Personal Income Tax in 2016 within the EU-28 was in Denmark (26\% of GDP), followed by Sweden and Finland. 


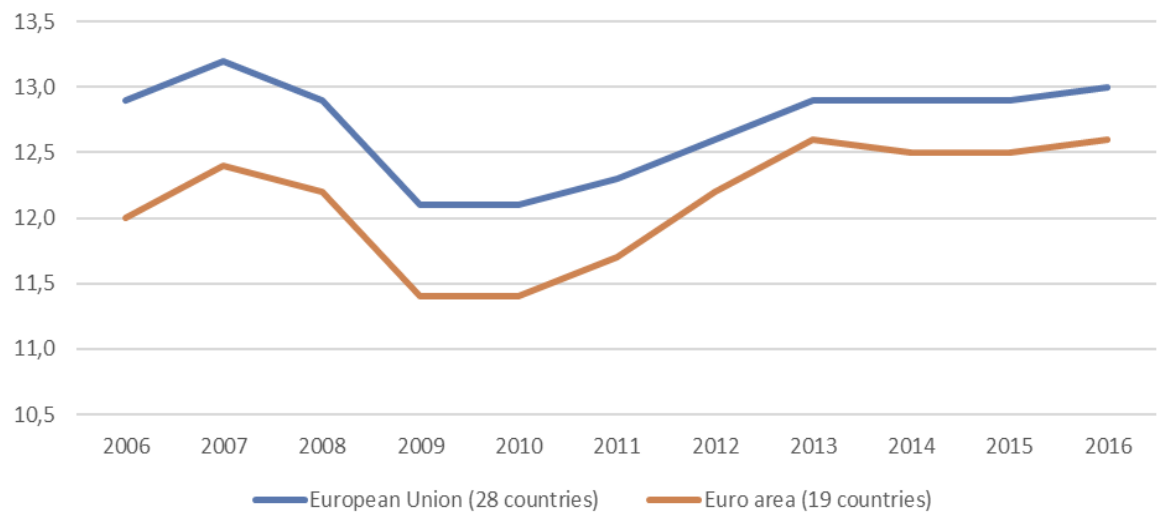

Figure 2. Current taxes on income, wealth, etc. (\% of GDP)

Sources: developed by the authors based on Eurostat data.

The lowest incomes from PIT was in Cyprus (2,5\% of GDP), followed by Bulgaria, Slovakia, Croatia and the Czech Republic. By and large, most of the Member States are above the zero axes. Over the decade, there has been an increase in the choice of Personal Income Tax in the Union (Figure 3).

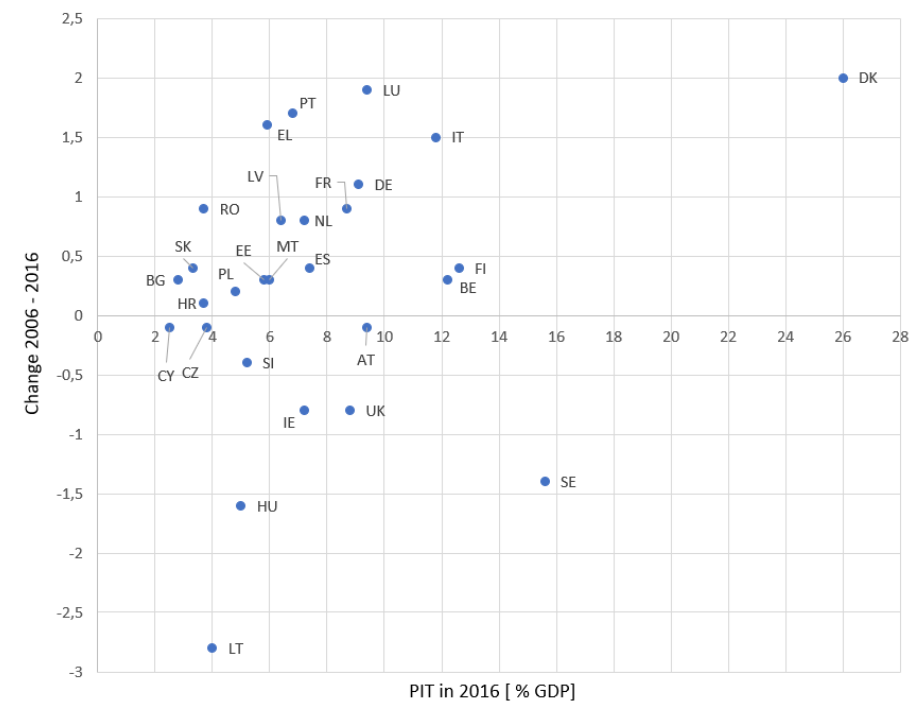

Figure 3. Personal Income Tax in 2006 and 2016 (\% of GDP)

Sources: developed by the authors based on Eurostat data.

In 2006 the average revenue from Corporate Income Tax was 3,0\% GDP in the EU-28. In 2016, this average indicator fell to 2,7\%. In 2016 (compared to reference the year 2006), CIT collection in six Member States increased, most in Malta $(2,6 \%)$ and Cyprus $(0,9 \%)$. On the other hand, Spain recorded the sharpest decline in comparison to the reference year $(-1,8 \%)$. Highest incomes from Corporate Income Tax in 2016 were in Malta, Cyprus (both 5,8\% GDP), and Luxembourg (4,6\% GDP). The lowest amount was levied by Estonia ( $0,2 \%$ GDP). Most of Member States are below the zero axes. Over the decade, there has therefore been a drop in Corporate IncomeTax in the Union (Figure 4). 


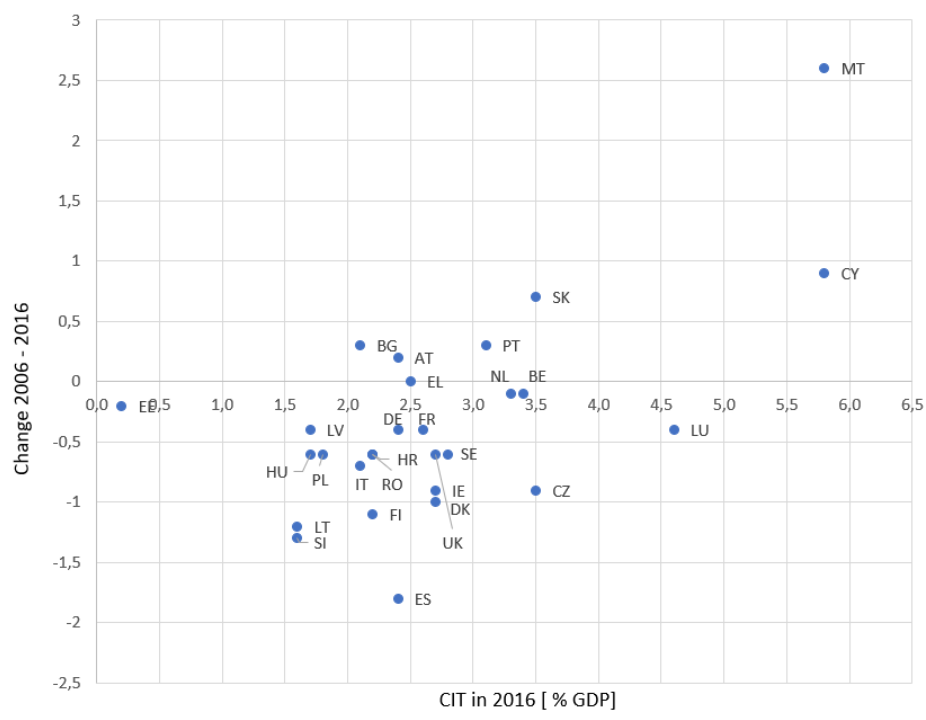

Figure4. Corporate Income Tax in 2006 and 2016 (\% of GDP)

Sources: developed by the authors based on Eurostat data.

As of 2016, the average personal income tax rate in the EU was 39\%, while the average corporate income tax rate was $22,5 \%$. Tax structures tend to be quite different among the Member States. The highest rate of Personal Income Tax was reported in Sweden, followed by Portugal and Denmark. At the end of the ranking was Bulgaria with a $10 \%$ rate. The same applies to the Corporate Tax Rate in Bulgaria. The highest CIT rate was recorded in Malta, France and Belgium in 2016 (Figure 5).

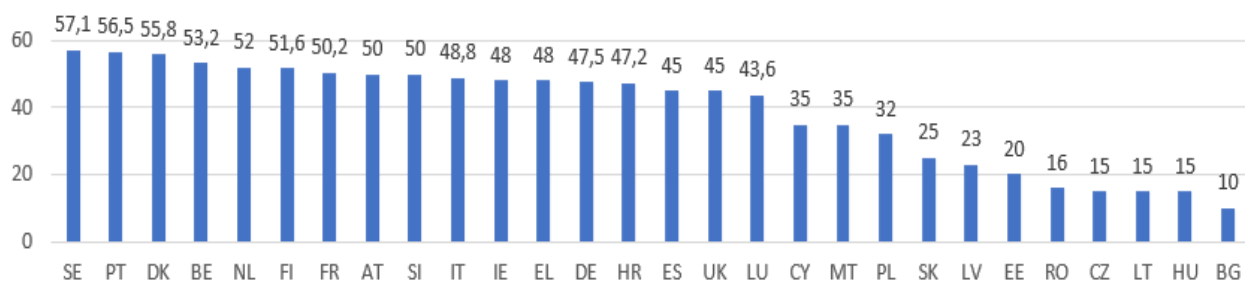

CIT rates

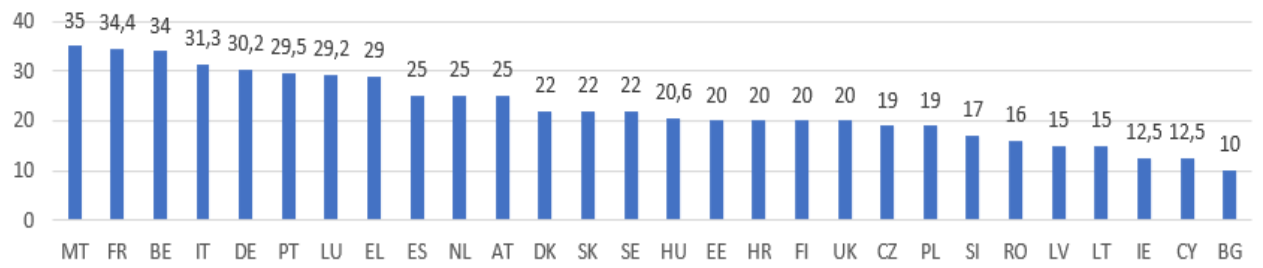

Figure 5. Top statutory PIT and CIT rates in 2016 (\%)

Sources: developed by the authors based on Eurostat data. 
Results. Imputed variables for cluster analysis were secondary data from the Eurostat database. The research method was cluster analysis conducted in statistical software R 3.3.3. There were used two clustering methods - hierarchical agglomerative clustering and non-hierarchical clustering. Two imputed variables for 28 Member States were PIT and CIT revenues in 2016. The objective of cluster analysis was to achieve such groups of states, which would be characterized by certain homogeneity in case of selected tax indicators. Cluster analysis sorted data into sets with the greatest possible similarity within the group and the largest difference between groups. The basic methods of clustering we used were:

1. Hierarchical methods are based on sequentially joining of clusters, their number decreases continuously until finally all clusters are combined into one. The result is graphically displayed as a tree diagram respectively cluster dendrogram.

Ward's method involves an agglomerative clustering algorithm. It looks for groups of leaves that it forms into branches, the branches into limbs and eventually into the trunk. Ward's method starts with $n$ clusters of size 1 and continues until all the observations are included in one cluster. Ward's method uses the Euclidean distance defined by the formula:

$$
d_{i j}=\sqrt{\sum_{k=1}^{K}\left(x_{i k}-x_{j k}\right)^{2}}
$$

where $x_{i k}$ is the value of «k» variable for $i$-th object and $x_{j k}$ is the value of «k» variable for $j$-th object.

For calculated distance is then determined the rule of linking statistical units into clusters. There were «p» objects in the analysed group, namely 28 countries in which were pursued «k» quantitative characters ( 2 variables), the distance $d \mathrm{~d}$ between $i$-th element and $j$-th element was Euclidean distance.

Table 2. Spearman's correlation coefficient (significance level $\alpha=0,05$ )

\begin{tabular}{|c|c|c|}
\hline & PIT & CIT \\
\hline PIT & 1.0000000 & 0.1597149 \\
\hline CIT & 0.1597149 & 1.0000000 \\
\hline
\end{tabular}

Sources: developed by the authors.

Cluster analysis assumes that the characters examined do not correlate with one another. Spearman's correlation coefficient has confirmed a low correlation between variables. In the dendrogram, we can identify five groups of countries with similar characteristics.

These groups are highlighted. There are two larger clusters with 9 or 11 countries, and two smaller clusters with 3 , respectively 4 states. Outside of clusters remained only Denmark. To draw conclusions that consider the exact distances, we have also used a non-hierarchical clustering method, the output of which is a scatterplot.

2. Non-hierarchical methods. If consider two variables, clusters can be visualized by using nonhierarchical method K-means. Based on previous hierarchical method, it is considered a similar number of clusters. K-means clustering is the most popular partitioning method. It requires the analyst to specify the number of clusters to extract. There are two components, which explain $100 \%$ of the point variability.

Due to testing, we have chosen 5 clusters as an imputed command for K-means clustering. We consider the data set, which contains $n=28$ objects, and partition it into $k=5$ clusters. The ellipses are based on the average and the covariance matrix of each cluster, and their size is such that they contain all the points of their cluster.

The ellipses sizes of clusters 2 and 3 are similar. Cluster no. 5 displays less variability of Component 2. Each cluster is quite extensive because of objects on boundaries of each ellipse. In cluster one stands out Estonia, in the fourth cluster is only Denmark. 


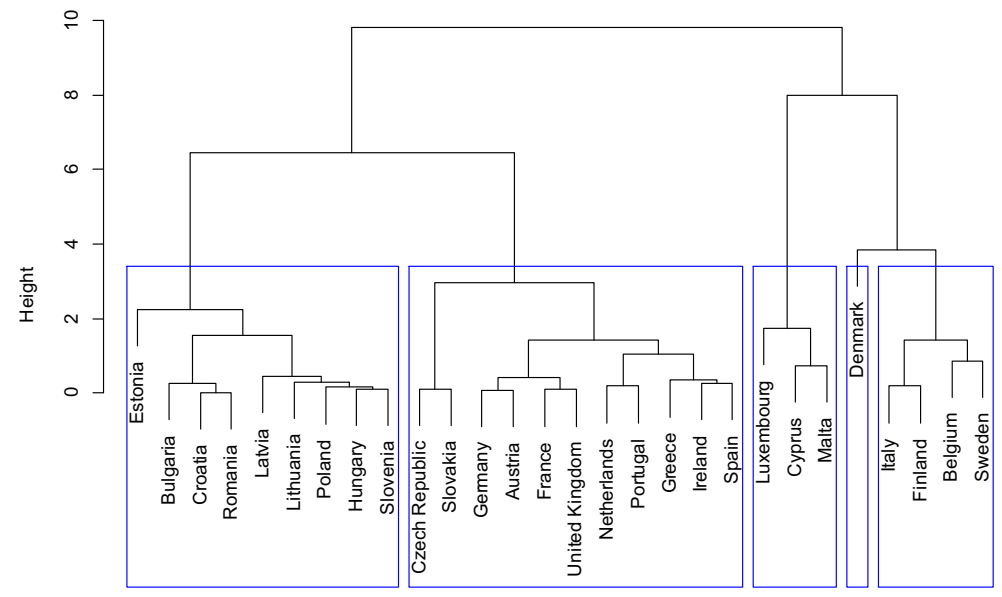

$\stackrel{d}{\text { hclust }\left({ }^{*}, \text { "ward.D") }\right.}$

Figure 6. Cluster dendrogram according to Ward's method (2016 data) Sources: developed by the authors.

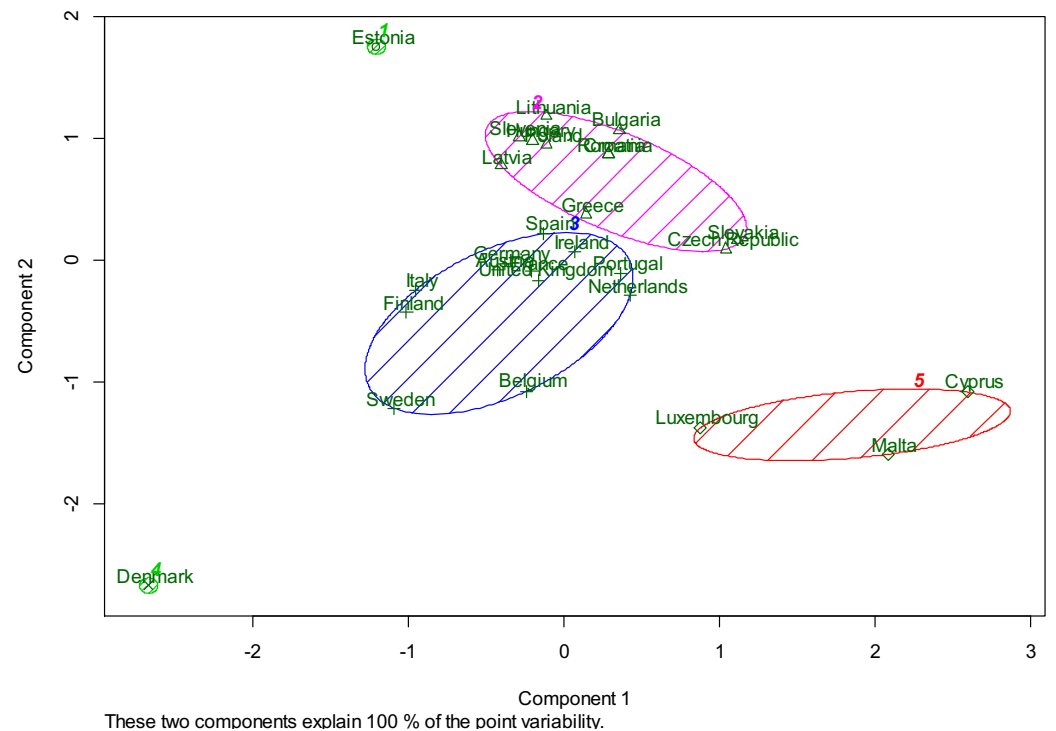

Figure 7. Scatterplot according to K-means method (2016 data)

Source: developed by the authors.

The larger shading intensity indicates the largest density of divided objects in ellipse respectively cluster 2 and 3 . For a better presentation of the results of non-hierarchical clustering method, the clusters are shown in the following Table 3. 
Table 3. Clusters according to K-means method (2016 data)

\begin{tabular}{|c|c|}
\hline Cluster no. 1 & Estonia \\
\hline Cluster no. 2 & $\begin{array}{c}\text { Lithuania, Bulgaria, Slovenia, Poland, Croatia, Hungary, Romania, Latvia, Greece, } \\
\text { Slovakia, Czech Republic }\end{array}$ \\
\hline Cluster no. 3 & $\begin{array}{c}\text { Spain, Ireland, Portugal, Germany, Austria, France, United Kingdom, Netherlands, Italy, } \\
\text { Finland, Sweden, Belgium }\end{array}$ \\
\hline Cluster no. 4 & Denmark \\
\hline Cluster no. 5 & Cyprus, Malta, Luxembourg \\
\hline
\end{tabular}

Sources: developed by the authors.

Conclusions. Direct taxes are a more significant barrier to the functioning of the internal market in the European Union than indirect taxes. They have a straight impact on free trade and are immediately and directly visible. On the other hand, direct taxes have more scattered effects. However, they have a significant impact on investment decisions, companies founding and employment. Therefore, it can be said that the different indirect taxes (shown in the analytical part of the paper) and the persisting competition between the Member States in this area significantly affect economic developments in the individual regions of the EU. It is questionable, whether, the differences between regions due to this tax competition are deepening or, the differences are more reduced. Of course, many other important factors influence such investment decisions. However, the fundamental differences in the real tax burden on labour, investment return, or double taxation, are a reality in the Union and all these affect the free movement of labour, the willingness to found companies, and so on. National tax systems represent, to a certain extent, an obstacle to the optimal allocation of production factors, which puts European businesses at a disadvantage, for example, with comparison to the US or Japan. Citizens of transit economies have never been accustomed to a high tax burden, especially in case of income taxes. Such a burden would hardly meet in these countries with understanding. However, the decisive factor in lower tax rates on income taxes is an economic reason. The transformation process in each country was accompanied by a fall in GDP and rising unemployment (except in the Czech Republic where the unemployment rate was very low). Reducing disposable income through taxation would only lead to low consumption of the population and a lack of investment resources. EU harmonization efforts mainly focus on legislation on taxes levied on goods and services (indirect taxes, such as VAT, excise duties levied on energy products, electricity, alcohol, and manufactured tobacco) rather than taxes on income or profits. Analysis of tax burden and income tax rates confirmed significant differences in these indicators within the EU. Together with the cluster analysis, however, they suggest possible steps for Member States' cooperation in the future. Economic and political developments in individual regions of Europe have unequivocally signed on the acceptance of fiscal burdens in the countries. Cluster analysis has also revealed similar developments in tax systems in terms of their geographic location in Europe. Therefore, it would be better at first to collaborate within the clusters, than try to apply uniform rules in all 28 countries at once. Since decisions can only be made by unanimity of all Member States, taxation measures in the European Union are not easy to adopt at all. The analysis carried out in this article shows that the Member States are largely different in the taxation of personal income and corporate profits. A practical benefit of cluster analysis is the recommendation to create the Member States groupings with similar approaches to taxation within the EU. First, they would exchange information, acquired experience about the functioning of tax systems, and so on. Subsequently, as teams within the integration group (EU), they would provide arguments in the negotiation of Union-wide tax rules. Thus, the attitudes of the 28 Member States could be reduced to a smaller number of conflicting ideas and strategies. This could subsequently lead to the facilitation of tax harmonization negotiations in the EU.

Author Contributions: Conceptualization, J. K. and R. B.; methodology, J. K.; software, R 3.3.3, J. K.; validation, I. V., R. B.; formal analysis, I. V., J. K.; investigation, I. V.; resources, R. B.; data curation, 
J. K.; writing - original draft preparation, I. V., J. K.; writing - review and editing, J. K., R. B.; visualization, J. K.; supervision, R. B.; project administration, R. B., I. V.; funding acquisition, R. B.

Funding: This article is one of the partial outputs under the scientific research grant VEGA 1/0806/16 «Research on issues of consumer behaviour of a new generation of customers with emphasis on identifying preferences and usability of mobile platforms in the process of e-commerce of the subjects localized predominantly on the Central European Market», VEGA 1/0789/17 - «Research of e-commerce with relation to dominant marketing practices and important characteristics of consumer behaviour while using mobile device platforms».

\section{References}

Bassanese, P. (2017). Income Tax Rates in the European Union. [online, quoted 12.01.2019]. Retrieved from http://digitalnomadeurope.com/income-tax-rates-european-union/

Belas, J., Gavurova, B., Kocisova, K., Delibasic, M. (2018a). Therelationshipbetweenassetdiversification and the efficiency of banking sectors in EU countries. Transformations in Business \& Economics, Vol. 17, Issue 3C, pp. 479-496.

Belas, J., Gavurova, B., Toth, P. (2018b). Impact of selected characteristics of SMEs on the capital structure. Journal of Business Economics and Management, Vol. 19, Issue 4, pp. 592-608. DOI: 10.3846/jbem.2018.6583.

Cnossen, S. (2018). Corporation Taxes in the European Union: Slowly Moving toward Comprehensive Business Income Taxation? In: International Tax. 25(3), p. 808-840.Retrieved from: http://dx.doi.org/10.1007/s10797-017-9471-2

Devereux, M. P. (2002). The OECD Harmful Tax Competition Initiative. [online, quoted 02.02.2019]. Retrieved from http://dx.doi.org/10.14217/9781848597587-10-en

Douma, S., Kardachaki, A. (2016). The Impact of European Union Law on the Possibilities of European Union Member States to Adapt International Tax Rules to the Business Models of Multinational Enterprises, INTERTAX, Vol. 44, Issue: 10, p. $746-754$.

Dzialo, J. (2015). Tax Competition Or Tax Coordination? What Is Better For The European Union? Comparative Economic Research, 18, 2.

European Commission. (2018). Taxation trends in the European Union - 2017 Edition. [online, quoted 01.12.2018].Retrieved fromhttps://ec.europa.eu/taxation_customs/sites/taxation/files/taxation_trends_report_2017.pdf.

European Commission. (2010). Taxation trends in the European Union - 2009 Edition. [online, quoted 10.01.2019]. Retrieved from: http://ec.europa.eu/taxation_customs/resources/documents/taxation/gen_info/economic_analysis/tax_structures/2009/2009_ main_results_en.pdf

Eurostat (2018). Government Finance and EDP Statistics. [online, quoted 20.02.2019]. Retrieved from: http://ec.europa.eu leurostat/web/government-finance-statistics/data/database

Fraley, Ch., Raftery, A. E., Murphy, B. T., Scrucca, L. (2012). Mclust Version 4 for R: Normal Mixture Modeling for Model-Based Clustering, Classification, and Density Estimation Technical Report No. 597. Department of Statistics, University of Washington.

Ganghof, S., Genschel, P. (2008). Taxation and democracy in the EU. JOURNAL OF EUROPEAN PUBLIC POLICY, Vol. 15, Issue: 1, p. 58-77. DOI: 10.1080/13501760701702199

Genschel, P., Jachtenfuchs, M. (2018). How the European Union constrains the state: Multilevel governance of taxation. European Journal Of Political Research, Vol. 50, Issue: 3, p. 293-314. DOI: 10.1111/j.1475-6765.2010.01939.x.

Hakalova, J., Palochova, M., Psenkova, Y., Bielikova, A. (2018). Regulation of Czech Accounting and Taxes in the Context of

European Accounting, Taxes and Ongoing International Harmonization, Proceedings Of The 4th International Conference On European Integration 2018 (ICEI 2018), PTS 1-3, p. 388-395. ISBN 978-80-248-4169-4.

Ivanova, E., Cepel, M. (2018). The Impact of Innovation Performance on the Competitiveness of the Visegrad 4 Conutries. Journal of Competitiveness, Vol. 10, Issue 1, pp. 54-72. DOI: 10.7441/joc.2018.01.04.

James, S., Nobes, CH. (1999). The Economics of Taxation. London: Pearson Education.

Kiselakova, D., Sofrankova, B., Cabinova, V., Onuferova, E., Soltesova, J. (2018). The Impact of R\&D Expenditure on the

Development of Global Competitiveness within the CEE EU Countries. Journal of Competitiveness, Vol. 10, Issue 3, pp. 34-50.

Kocisova, K., Gavurova, B., Behun, M. (2019). the importance of ImplementingEnvironmentalVariables in the process of Assessment of Healthcare Efficiency through DEA. Ekonomicky casopis, Vol. 67, Issue 4, pp. 367-387.

Kubatova, K. (2003). Danovateorie a politika. Praha: ASPI. 276 p. ISBN 9788074788413.

Medved, J., Nemec, J. et al. (2011). Verejnefinancie. Bratislava: Sprint. 640 p. ISBN 9788089393466

Mitchell, D. (2005): Danovaharmonizacia vs. konkurencia v Europskejunii. [online, quoted 15.12.2018]. Retrieved from:

http://www.konzervativizmus.sk/article.php?660

Nerudova, D. (2011). Harmonizace danovych systemu zemi Evropskeunie [Harmonization of the tax systems of the European Union]. Praha: Wolters Kluwer. 319 p. ISBN 9788073576950. 
Nerudova, D. (2008). Tax Harmonization in the EU. [online, quoted 06.01.2019]. Retrieved from: http://mibes.teilar.gr/ebook/ebooks/Nerudova\%2090-109.pdf

Niazi, S. U.K. (2016). Tax Harmonization in the EU: Insights on Political and Legal Fusion under Neofunctional Rationale JOURNAL OF POLITICS AND LAW, Volume: 9, Issue: 4, p.15-29.

Pensylvania State University. (2004). Cluster analysis. [online, quoted 02.02.2019]. Retrieved from: http://sites.stat.psu.edu/ ajw13/stat505/fa06/19_cluster/09_cluster_wards.html

Ponomareva, K. (2016). Tax Law of the Eurasian Economic Union: Substance and Ways of Using of the European Experience, EC TAX REVIEW, Vol. 25, Issue: 2, pp. 94-108.

Prichard, W., Cobham, A., Goodall, A. (2014). The ICTD Government Revenue Dataset. [online, quoted 15.01.2019]. Retrieved from: https://opendocs.ids.ac.uk/opendocs/bitstream/handle/123456789/10250/ICTD_WP19.pdf?sequence=1

Psenkova, Y. (2016). Comparison of tax burden of incomes from the dependent activity of employees in the Czech republic and Slovak republic in the context of globalization trends. Conference: 16th International Scientific Conference on Globalization and its Socio-Economic Consequences, Univ Zilina, Fac Operat \& Econ Transport \& Commun, Dept Econ, p. 1832-1839.

Riedel, R. (2018). Differentiated Integration and Monetary Union in Europe, Proceedings of the 4th International Conference on European Integration 2018. (ICEI 2018), PTS 1-3, pp. 1233-1239.

Simionescu, M. (2016). Competitiveness and Economic Growth in Romanian Regions. Journal of Competitiveness, Vol. 8, Issue 4, pp. 46 - 60. DOI: $10.7441 /$ joc.2016.04.03

Siroky, J. (2010). Danev Evropskeunii. Praha: LINDE. 352 p. ISBN 9788072017997.

Siroky, J. (2008). Danoveteorie s praktickouaplikaci. Praha: C. H. Beck. 301 p. ISBN 8074000058.

Tkacova, A., Gavurova, B., Behun, M. (2017). The Composite Leading Indicator for German Business Cycle. Journal of Competitiveness, Vol. 9, Issue 4, pp. 114-133. DOI: 10.7441/joc.2017.04.08.

Vojtovic, S. (2016). The Impact of the Structural Funds on Competitiveness of Small and Medium-Sized Enterprises. Journal of Competitiveness, Vol. 8, Issue 4, pp. 30-45. DOI: 10.7441/joc.2016.04.02

Ярослав Коречко, Ph.D., Прешівський університет (Словаччина);

Радован Бацик, Ph.D., доцент, Прешівський університет (Словаччина);

Івета Вознакова, Ph.D., доцент, Університет бізнесу та права (Чехія).

Державне управління в ЄC: гармонізація податків на прибуток

У європейських країнах гармонізація системи оподаткування розпочата з появою інтеграційних процесів у 1960-х роках. Основна ідея полягала не лише у структурній гармонізації податків, а й у рівні їх ставок. У статmі досліджено характер та хід процесу узгодження прямого податку, виокремлено його переваги та недоліки, а також позитивні та негативні наслідки податкової конкуренції. Метою статmі є вивчення специфіки розвитку та аналіз динаміки зміни обсягів податків на прибуток, сплачених в країнах-членах Європейського Союзу. Авторами проаналізовано етапи та ефективність гармонізації систем оподаткування прибутку в країнах Європейського Союзу. Методологічним базисом дослідження виступив кластерний аналіз, що дозволив виявити подібність багатовимірних об'єктів аналізу. У статmі використано два методи кластеризації, а саме: кластеризація ієрархічної агломерації та неієрархічна кластеризація. Метою кластерного аналізу було виокремлення груп країн, які мали певну однорідність, сортуючи дані в кластери з найбільшим рівнем подібності у групі та найбільш істотною різницею між групами. Аналіз податкового навантаження та ставок податку на прибуток підтвердив значні відмінності в цих показниках у всіх країнах Європейського Союзу. 3 іншого боку, кластерний аналіз виявив подібні зміни в податкових системах з точки зору їх географічного розташування в Європі. Авторами запропоновано механізми активізації процесу гармонізації системи оподаткування, а саме: на першому етапі синхронізувати податкові системи у кластерах, а на другому - між кластерами. У статmі зазначено, що низка країн-членів Європейського Союзу мають автономію у прийнятті рішення про податковий тягар у країні, оскільки вони бачать цю автономію як конкурентну перевагу, особливо у сфрері інвестицій. Це у свою чергу, дестабілізує систему оподаткування в Європейському Союзі.

Ключові слова: податок, гармонізація, дохід, Європейський Союз, кластерний аналіз.

Manuscript received: 17.05.2019.

(C) The author(s) 2019. This article is published with open access at Sumy State University. 